\title{
Cellular and physiological effects of anthrax exotoxin and its relevance to disease
}

\section{David E. Lowe and lan J. Glomski*}

Department of Microbiology, Immunology, and Cancer Biology, University of Virginia Health System, Charlottesville, VA, USA

Edited by:

Ken Bradley, University of California

Los Angeles, USA

\section{Reviewed by:}

Ken Bradley, University of California

Los Angeles, USA

Janice Endsley, University of Texas

Medical Branch, USA

*Correspondence:

lan J. Glomski, Department of

Microbiology, Immunology, and

Cancer Biology, University of Virginia

Health System, 1340 Jefferson Park

Avenue, PO Box 800734, Jordan Hall,

Room 7231, Charlottesville, VA

22908, USA.

e-mail: iglomski@virginia.edu
Bacillus anthracis, the causative agent of anthrax, secretes a tri-partite exotoxin that exerts pleiotropic effects on the host. The purification of the exotoxin components, protective antigen, lethal factor, and edema factor allowed the rapid characterization of their physiologic effects on the host. As molecular biology matured, interest focused on the molecular mechanisms and cellular alterations induced by intoxication. Only recently have researchers begun to connect molecular and cellular knowledge back to the broader physiological effects of the exotoxin. This review focuses on the progress that has been made bridging molecular knowledge back to the exotoxin's physiological effects on the host.

\section{Keywords: lethal toxin, edema toxin, B. anthracis, immunology, cardiovascular}

\section{INTRODUCTION}

Bacillus anthracis is a Gram-positive sporulating bacterium that is the causative agent of anthrax (Mock and Fouet, 2001). The bacterium has two key virulence factors: a poly- $\gamma$-D-glutamic acid capsule produced by gene products encoded on the pX02 plasmid and a tri-partite exotoxin encoded on the pX01 plasmid (Mikesell et al., 1983; Green et al., 1985). The exotoxin is composed of a host-cell receptor binding protein named protective antigen (PA) and two enzymatic proteins, lethal factor (LF) and edema factor (EF; Stanley et al., 1960; Smith and Stanley, 1962). LF and EF have no known activity on the host until they bind and then are subsequently translocated to the target-cell cytosol by PA. Once LF or $\mathrm{EF}$ is bound to PA, they are referred to as lethal toxin (LT) or edema toxin (ET), respectively. For most hosts, bacteria must have both the capsule and the exotoxin in order to be fully virulent. Resultantly, exotoxin deficient mutants have been used as vaccine strains in animal models since the nineteenth century (Sterne and Robinson, 1939; Tigertt, 1980). However, the elimination of exotoxin production in some $B$. anthracis strains, such as the Ames strain, does not affect virulence in mice, while other strains, such as UT500, have decreased virulence in cutaneous models of infection when exotoxin production is eliminated (Welkos et al., 1993; Heninger et al., 2006; Chand et al., 2009).

Host-cell intoxication begins when PA binds to either tumor endothelial marker 8 [TEM8, also known as anthrax toxin receptor 1 (ANTXR1)] or capillary morphogenesis gene 2 [CMG2, also known also anthrax toxin receptor 2 (ANTXR2); Bradley et al., 2001; Scobie et al., 2003; Young and Collier, 2007]. PA can also bind to $\beta 1$ integrins, which potentiate the uptake of PA by macrophages (Martchenko et al., 2010). The physiological role of TEM8 in mammals has been implicated in binding the extracellular matrix, directing endothelial migration and adhesion (Nanda et al., 2004;
Hotchkiss et al., 2005). Less is known about CMG2 but evidence suggests a role in endothelial proliferation (Reeves et al., 2010). As their names and functions suggest, TEM8 and CMG2 are highly expressed in vasculature, but several studies have also noted their presence in epithelial cells (particularly in respiratory epithelium, intestines, and keratinocytes) as well as in immune cells (Bradley et al., 2001; Scobie et al., 2003; Bonuccelli et al., 2005). Genetic and biochemical studies have recently demonstrated that PA has higher affinity for CMG2 and plays a larger role in susceptibility than TEM8 in mice (Liu et al., 2009). After PA binds to CMG2 or TEM8, it is cleaved by furin to a $63 \mathrm{kDa}$ isoform $\left(\mathrm{PA}_{63}\right)$ which heptamerizes (Milne et al., 1994; Gordon et al., 1995; Lacy et al., 2004). Alternatively, PA can be cleaved by serum proteases independently from cell binding (Ezzell and Abshire, 1992; Moayeri et al., 2007). Reports differ, however, as to whether this phenomenon is a species specific effect in mice or occurs in several animal models. While the exact protease has not been discovered, it is sensitive to the protease inhibitor leupeptin, heat sensitive, and dependent on calcium. Once $\mathrm{PA}_{63}$ has heptamerized, it can bind both LF and EF with up to three potential binding sites per heptamer (Mogridge et al., 2002a,b). A more recent study also provides evidence that PA can oligomerize into either a heptamer or an octomer. In comparison to the heptamer, the octomer is more stable when unbound to the host toxin receptor, perhaps enabling it to oligomerize and pre-form the exotoxin complex in serum (Kintzer et al., 2009).

Protective antigen oligomerization is necessary for its association with lipid rafts and clathrin-mediated endocytosis (Abrami et al., 2003). After endocytosis, the exotoxin is sorted into intraluminal vesicles in the early endosome (Abrami et al., 2004). The decreasing $\mathrm{pH}$ in the early endosome causes PA/TEM8 to undergo a critical conformational change to insert into the membrane and form a translocation pore (Milne et al., 1994). PA bound 
to CMG2, however, needs a lower pH than TEM8 (Rainey et al., 2005). In either case, this leads to LF/EF translocation into the intraluminal vesicle, which then reaches the cytosol when the intraluminal vesicles fuse back into the late endosome membrane or the autophagosome (Abrami et al., 2004; Ha et al., 2010).

Once in the cytosol, LF and EF can exert their effects on the cell. $\mathrm{LF}$ is a zinc metalloprotease that cleaves the $\mathrm{N}$-terminus from several MEKs and prevents the activation of Erk1/2, p38, and JNKpathways (Duesbery et al., 1998; Pellizzari et al., 1999; Vitale et al., 2000). EF is a calmodulin dependent adenylyl cyclase toxin that raises cAMP levels to supra-physiological levels (Leppla, 1982). In contrast to other cAMP elevating toxins, such as Bordetella pertussis adenylate cyclase toxin and cholera toxin, ET produces high amounts of cAMP perinuclearly rather than at the cell membrane (Dal Molin et al., 2006). The increased cAMP can then activate protein kinase A (PKA), exchange protein activated by cAMP (Epac), and the guanine exchange factor Rap1 (Hong et al., 2007).

It should not escape notice that these exotoxins act on key signaling pathways that are present in several types of cells across many physiological systems. Similarly, TEM8 and CMG2 are highly expressed in a myriad of tissues, allowing for the exotoxin to act on several systems simultaneously. This has complicated the understanding of the exotoxin's effects on the host since these pathways have several targets in a cell, which can lead to unique effects for different cell types and organs. Since the 1950s, when the exotoxins were first purified and characterized as sufficient to cause lethality, tissue edema, or protection from subsequent infection, research has been aimed to define the molecular mechanisms of their actions. This review seeks to discuss how the cellular and molecular mechanisms of cell intoxication caused by the $B$. anthracis exotoxins lead to diverse, and at times contrary, physiological and cellular changes in the host's immune, cardiovascular, endocrine, and nervous systems.

\section{IMMUNOLOGICAL EFFECTS}

The ability of $B$. anthracis to subvert the immune system is of the utmost importance for the pathogen to complete its lifecycle (Mock and Fouet, 2001). This fact has not escaped the attention of researchers as there are a multitude of studies and reviews that investigate how anthrax toxins affect the immune system in order to establish and exploit a niche in the host (Baldari et al., 2006; Tournier et al., 2009). This review will focus on the effects of anthrax exotoxins on three main immunological functions: chemotaxis, bacteriocidal activity, and exotoxin induced pyroptosis/apoptosis of immune cells.

\section{CHEMOTAXIS}

Neutrophils are among the first immune cells to respond to infections and are essential for clearance of many bacterial and fungal pathogens. Therefore, it stands to reason that a swift influx of neutrophils is necessary to contain an infection by $B$. anthracis. Indeed, some studies have indicated that neutrophils are necessary for protection due their antibacterial activities (Liu et al., 2010). Further, early production of pro-inflammatory cytokines, such as IL-1 $\beta$, can increase survival mediated by neutrophils (Moayeri et al., 2010). Both purified LT and ET inhibit neutrophil chemotaxis by reducing F-actin formation in vitro (During et al.,
2005; Szarowicz et al., 2009). This leads to reductions in random velocity, directed velocity toward formyl-Met-Leu-Phe (a well characterized chemoattractant) and reduces polarization of the leading and lagging edges of the cell. F-actin is further reduced when the cells are treated with both LT and ET simultaneously, demonstrating an additive role for both exotoxins (Szarowicz et al., 2009). ET also reduces the expression of CD11b/CD18 (Mac-1 or CR3), a $\beta 2$ integrin that is important in neutrophil adhesion and extravasation. This presumably would reduce diapedesis through capillaries or epithelial layers to the site of infection; however, this was not tested (Szarowicz et al., 2009). These studies are in contrast to earlier work from Wade et al. (1985) which found ET increases $\mathrm{PMN}$ chemotaxis and an in vivo observation that greater amounts of neutrophils were found near injection sites of ET (Tessier et al., 2007). The latter observation may reflect the indirect effects of ET increasing production of inflammatory lipid mediators which recruit neutrophils.

Macrophage chemotaxis is altered by both LT and ET similarly to neutrophils. In vivo clodronate depletion of macrophages sensitizes mice to infection during inhalational anthrax, demonstrating a net protective function of macrophages (Cote et al., 2004, 2006). In vitro treatment of macrophages and peripheral blood lymphocytes with either purified LT or ET reduces phosphorylation of Erk, presumably by independent mechanisms, which lessens chemotaxis toward the chemoattractants SDF- $1 \alpha$ and MIP$1 \alpha$ (Rossi Paccani et al., 2007). Pharmacologically inhibiting Erk phosphorylation with the MEK inhibitor PD98059 also reduces chemotaxis, supporting the interpretation that the exotoxins are targeting the MAPK pathway to reduce chemotaxis. Additionally, the ET inhibitor adefovir is able to partially rescue chemotaxis. Interestingly, the F-actin decrease found in During et al.'s (2005) research was not observed in neutrophils treated with PD98059, suggesting that chemotaxis was not inhibited in their experimental system. This could be due to MEK1 having unique effects in macrophages and neutrophils or the F-actin reduction occurs via another MAPK pathway. Similarly, purified ET increases the cell migration of bone marrow derived macrophages (BMDM; Kim et al., 2008). This migration is due to PKA stimulation activating CREB. Several genes are then induced via CREB, including $S d c 1$, which is necessary for the increased migration and actin redistribution that occurs in ET-treated BMDMs. It is important to note that there is no indication that the macrophages were moving in the direction of a chemoattractant. This is a salient point in $B$. anthracis exotoxin-mediated chemotaxis assays since an increase in random migration is distinct from chemotaxis. As such, differentiation between random migration versus chemotaxis should be noted when interpreting these observations. Recombinant ET administration, however, leads to an increase in total circulating neutrophils and monocytes (Firoved et al., 2005). This may be the result of an increase in chemotaxis out of the bone marrow, as the bone marrow is depleted of pluripotent stem cells. Indeed, GCSF, a potent maturation factor for neutrophil progenitors, has a cAMP response element in its promoter, which may explain both the marked increase of neutrophils and G-CSF in the serum.

Lastly, dendritic cells (DCs), which represent a crucial link between innate and adaptive immunity, have an increased ability to chemotax and invade matrigel when treated with purified 
ET (Maldonado-Arocho and Bradley, 2009). LT has been shown to inhibit chemotaxis in PBMC's; however, addition of purified LT with ET also leads to an increase in chemotaxis compared to untreated DCs (Rossi Paccani et al., 2007; Maldonado-Arocho and Bradley, 2009). Additionally, recombinant ET is capable of activating glycogen synthase kinase (GSK) in DCs, which in turn is able to fully activate CREB-mediated transcriptional changes shown by Kim et al. to be involved with chemotaxis (Kim et al., 2008; Larabee et al., 2011). It is unknown if GSK is involved with CREB activation in either neutrophils or macrophages.

\section{BACTERICIDAL ACTIVITY}

In addition to their potent actions on chemotaxis, the B. anthracis exotoxins are also able to reduce the bactericidal activity and activation of the innate immune system. Intoxicating human neutrophils with purified ET reduces phagocytosis, which is not surprising given the potent effect ET has on neutrophil actin formation (O'Brien et al., 1985). Additionally, purified ET reduces the neutrophil's oxidative burst. Recombinant LT's role in the neutrophil oxidative burst has also been examined with two discordant studies showing it either increases or decreases the oxidative burst in human neutrophils (Crawford et al., 2006; Xu et al., 2008). Purified LT also reduces the amount of pro-inflammatory cytokines and chemokines in NB-4 cells, a neutrophil-like immortal cell line (Barson et al., 2008). The effects of LT on human neutrophils may be less pronounced due to the ability of human $\alpha$-defensins to neutralize LT, though it is unclear in what environments in vivo $\alpha$-defensin concentrations would be at sufficiently high levels to mediate this inhibition (Kim et al., 2005).

While it is tempting to assume that an exotoxin's effect on the bactericidal activity of circulating phagocytes will be similar to that of a resident phagocyte, research has indicated there are important differences. Resident phagocytes have previously been implicated as acting as a Trojan horse for B. anthracis spores (Ross, 1957; Dixon et al., 2000; Guidi-Rontani, 2002). That is, the spore is phagocytosed by alveolar macrophages (AMs) or lung DCs, which then migrate with the spore to the draining mediastinal lymph node. During the migration, the spore germinates, replicates, and escapes from the phagocyte into the lymph node from which it can later spread to the blood. However, human AMs are more resistant to MEK1 cleavage and LT-mediated cytokine inhibition than peritoneal macrophages or the murine RAW264.7 macrophagelike cell line (Wu et al., 2009). Further, PA does not bind AMs well, despite similar transcription levels of CMG2 compared to RAW264.7 cells. This might be due to single nucleotide polymorphisms (SNPs) in human macrophages. Genetic susceptibility to exotoxin uptake was explored in an in vitro system where lymphoblastoid cells derived from 234 cohorts in the HapMap Project (Martchenko et al., 2012). Cells were treated with PA and FP59, a heterologous cargo protein for the PA oligomer that rapidly kills lymphocytes in a manner independent from either LT or ET, to assess their relative capacity for intoxication. Susceptibility to intoxication varies 30,000-fold, with three cell lines showing a much higher level of resistance. Excluding these three outliers, there is still a 250 -fold range of resistance between individuals. This suggests that human cells have varying ability for exotoxin uptake. Further, a SNP that causes a P357A substitution in the human CMG2 region involved with PA internalization reduces the amount of PA uptake in transgenic RAW264.7 cells (Martchenko et al., 2012). It is likely, however, that AMs are uniquely resistant to LT-mediated death as the AMs in Wu's studies were likely collected from several individuals. AMs from Cynomolgus macaques, however, do have reductions in cytokine production when intoxicated with purified LT in vitro, likely due to the effects of MEK1 cleavage (Ribot et al., 2006). Therefore, in addition to differential responses between human and mouse AMs, important species difference in the intoxication of immune cells exist even in very closely related non-human primates and humans. Despite the difference in cytokine production, both studies demonstrate stark differences in the viability of AMs when compared to circulating monocytes/macrophages and macrophage-like cell lines (Pellizzari et al., 1999; Popov et al., 2002; Wu et al., 2009). ET intoxication of Guinea pig AMs with purified ET reduces their secretion of Type-IIA phospholipase A2 (Raymond et al., 2007). This enzyme not only activates innate immunity through the production of arachidonic acid, but also is able to exert a direct bactericidal activity. Accordingly, infection of Guinea pigs with an EF deficient $B$. anthracis strain does not reduce phospholipase A2 activity. It would be interesting to determine if ET can induce increased cAMP and a decrease in Type-IIA phospholipase A2 in human AMs given the report of poor PA binding to these cells.

There is also conflicting data as to whether circulating monocytes/macrophages produce more or less pro-inflammatory cytokines after exposure to purified LT. This is in part due to the ability of macrophages in some rodent inbred strains to undergo pyroptosis in response to LT intoxication (described in further detail below; Friedlander et al., 1993; Hanna et al., 1993; Bergsbaken et al., 2009). Addition of LT to monocytes prevents differentiation into macrophages in vitro (Kassam et al., 2005) and reduces the amount of TNF $\alpha$ and IL- $1 \beta$ produced by macrophages in response to stimuli (Erwin et al., 2001). Further, both low doses of recombinant LT and ET reduce the ability of macrophages to phagocytose (Yeager et al., 2009; Kau et al., 2010). In agreement with the protective roles of macrophages, spore-infected mice supplemented with mutant macrophages that are resistant to LT-mediated lysis (see more details below) had higher survival rates than those supplemented with exotoxin-sensitive RAW264.7 cells. The mice with the mutant LT-resistant macrophages had lower bacterial burdens $18 \mathrm{~h}$ post-infection than controls. There is no difference in mouse survival between mutant LT-resistant and parental macrophages when infected with vegetative bacteria, potentially indicating an exotoxin-independent mechanism, such as capsule for phagocyte evasion (Cote et al., 2008).

NK cells were first identified as being involved in anthrax immunity when it was noted that formaldehyde inactivated spores (FIS) induce a large increase in IFN- $\gamma$ and IL-12p40 in murine splenocytes (Glomski et al., 2007). Incubating splenocytes with anti-IL-12 antibodies abrogates the increase in IFN- $\gamma$ production, strongly suggesting that IL-12 production is necessary for the increase in IFN- $\gamma$. Further, this increase is dependent on MyD88 signaling as splenocytes from $\mathrm{MyD} 88^{-1-}$ mice do not respond with an increase of either of these cytokines. Within the spleen, the $\mathrm{CD}_{11} \mathrm{~b}^{+}$population (macrophages and some DCs) are responsible for the IL-12 production, whereas the CD $49 \mathrm{~b}^{+}$population (the 
majority of NK and NKT cells) produces the IFN- $\gamma$. Addition of purified LT to splenocytes disrupts a paracrine feedback loop that is known to increase the bacteriocidal activity of macrophages and monocytes as well as increase inflammation in the host.

A recent study further delineated the mechanism of the macrophage-NK interactions and its role in vivo (KlezovichBénard et al., 2012). BMDM induce IFN- $\gamma$ production in NK cells after exposure to $B$. anthracis spores through direct contact of macrophage RAE-1 ligand to their activating NKG2D receptor. Neutralization of either RAE-1 or NKG2D by monoclonal antibodies led to a decrease in IFN- $\gamma$ and this IFN- $\gamma$ decrease is additive if both antibodies are included. Furthermore, addition of spores to BMDM led to an increase in RAE-1 expression. RAE-1 is expressed due to TLR signaling through MyD88, in agreement with the previous publication noting that MyD88 is necessary for this macrophage-NK paracrine function (Hamerman et al., 2004). Furthermore, IL-18 and IL-15 are necessary for the IL-12 mediated IFN- $\gamma$ production. Purified LT decreases IFN- $\gamma$ release from NK cells by preventing IL-12/IL-18 production via reduced phosphorylation of p38, JNK, and ERK. LT treatment does not lead to increases in cell death as determined by cell permeability, but it does reduce metabolism when analyzed using mitochondrial reductase assay. While purified LT acts on NK cytokine secretion, purified ET leads to only a slight reduction in IFN- $\gamma$ production at high concentrations when splenocytes are exposed to FIS. However, purified ET reduces IL-12 released by macrophages/DCs to basal levels, thereby reducing IFN $-\gamma$ production indirectly. ET also reduces IL-18 production when exposed to FIS, as addition of IL18 can restore IFN- $\gamma$ levels in splenocytes treated with purified ET. Further, both purified LT and ET reduce the ability of NK cells to lyse MHC class I-deficient cells in vitro and in vivo. Lastly, infection of mice with either ET only or LT only-expressing strains leads to a decrease in migration of $\mathrm{NK}$ and $\mathrm{F} 4 / 80^{+}$cells to draining lymph nodes.

Gonzales et al. (2012) similarly found a decrease in IFN- $\gamma$, but no changes in apoptosis when incubating human NKs and monocytes with purified LT. Conversely to mouse NK cells, human NK cells treated with purified LT or ET were still capable of lysing MHC class I-deficient K562 cells. Both studies demonstrated the NKs delayed dissemination of B. anthracis in both cutaneous and inhalational models of infection; however, Gonzales et al. noted that NK deficiency did not alter the pathology or the survival kinetics. In agreement with this, NK cells greatly enhance the bactericidal activity of infected monocytes and surprisingly can cause a $\sim 2 \log _{10}$ decrease in extracellular vegetative bacilli. While NK-macrophage/monocyte enhancement was well described in Klezovich-Bénard's work, the mechanism by which NK cells are able to kill bacilli is unknown. The authors suggest that natural cytotoxicity receptors, which have been shown to have an effect on other bacteria, may bind a yet to be discovered ligand on $B$. anthracis. It is unknown if the activity of these cytotoxic receptors are altered by exotoxin.

Lethal toxin can also induce anergy in Type I CD1d-restricted natural killer T (NKT) cells (Joshi et al., 2009). These cells are a class restricted $\mathrm{T}$ cell that express a semi-invariant $\mathrm{T}$ cell receptor, CD1d lipid specific antigen presentation molecule, and the NK1.1 molecular marker. These cells occupy a unique niche in the host between the innate and adaptive immune systems. NKT cells also express CMG2 and TEM8 at greater quantities and bind PA to a greater extent than other splenocytes. Intoxication with purified LT led to a large decrease in NKG2D expression by NKTs, yet this is not seen in NK cells. Further, addition of purified LT to NKT cells led to decreases in CD69 as well as increases in Ly49 inhibitory receptors. Similarly to NK cells, there was no decrease in cell viability. NKT cells are also noted for their ability to be stimulated with the glycolipid alpha-galactosylceramide ( $\alpha$-GC) to produce IFN- $\gamma$ and IL-4. Ex vivo stimulation of splenocytes with $\alpha-\mathrm{GC}$ from a mouse treated with purified LT led to a decrease in both IL4 and IFN- $\gamma$. Co-culture assays using splenocytes harvested from an NKT deficient mouse treated with purified LT and LT treated NKTs expanded ex vivo demonstrate that the IFN- $\gamma$ production comes from the NKT cell and that splenocytes and NKT cells are synergistically involved in IFN- $\gamma$ production.

Dendritic cells, $\mathrm{T}$, and $\mathrm{B}$ cells are also affected by exotoxins, though as mentioned in a previous review, it is not certain what role this plays given that anthrax is an acute disease and there is evidence that survivors have long lasting immunity (Ingram et al., 2010; Moayeri and Leppla, 2011). It is possible that DCs, T, and B cells increase the activation and bacteriocidal activity of the innate immune system indirectly through cytokine and chemokine production. In support of this, in vitro addition of purified exotoxins reduce the amount of pro-inflammatory cytokines produced by human and murine DCs (Agrawal et al., 2003; Brittingham et al., 2005; Tournier et al., 2005; Cleret et al., 2006). Splenic DCs that are intoxicated with purified LT are deficient in stimulating $\mathrm{T}$ cell proliferation (Agrawal et al., 2003). Further, there is evidence that purified LT can induce cell death in immature, but not mature, DCs (Alileche et al., 2005; Reig et al., 2008). This is complicated by the fact that recombinant ET can induce maturation of immature DCs, a feature that has been demonstrated with other cAMP increasing agents (Galgani et al., 2004; Maldonado-Arocho and Bradley, 2009). It is worth noting that DCs are a very diverse class of cells that originate from separate precursors and have different roles (Banchereau et al., 2000). Thus, anthrax exotoxins may have unique effects on different subtypes of DCs. In support of this, bone marrow derived DCs infected with a $B$. anthracis strain expressing both exotoxins do not have defects in maturation (Tournier et al., 2005; Cleret et al., 2006). Yet, infecting lung DCs (LDCs) with spores from a strain that produced LT only or both LT and ET leads to a decrease in LDC activation (Cleret et al., 2006). Therefore, it is possible that in addition to AMs, resident lung DC's have unique responses to LT and ET and LDCs may be specifically targeted by LT in inhalational infections.

Beyond the previously mentioned decrease in DC-mediated stimulation of T and B cells, both LT and ET are capable of directly suppressing immune cell proliferation, similar to the effect of ET on the murine J774.A1 macrophage-like cell line (Comer et al., 2005; Paccani et al., 2005; Fang et al., 2006; Gray and Hewlett, 2010). Purified exotoxins are also sufficient to reduce cytokine and IgM production (Fang et al., 2006). As discussed above, T and $\mathrm{B}$ cells have powerful roles in regulating the innate immune system and may have an important role in directing the innate immune response. This is underscored by purified ET inducing the development of $\mathrm{T}$ helper cells to a $\mathrm{T}_{\mathrm{H}} 2$ and $\mathrm{T}_{\mathrm{H}} 17$ phenotype, depending 
on the amount of ET added (Rossi Paccani et al., 2009; Paccani et al., 2011). The latter development is surprising given that $T_{H} 17$ invokes a potent antimicrobial effect. At present, there is little data on the effect of LT on T helper polarization, so it is unknown if these effects would be mitigated during co-intoxication. It is tempting to speculate that the reduction of IFN- $\gamma$ from NK cells plays a role in this polarization toward $\mathrm{T}_{\mathrm{H}} 2 / \mathrm{T}_{\mathrm{H}} 17$.

\section{PYROPTOSIS AND APOPTOSIS OF IMMUNE CELLS}

Finally, host immune cells are particularly susceptible to multiple forms of cell death when intoxicated by B. anthracis' exotoxins. Macrophages are vulnerable to LT-mediated death (Friedlander, 1986; Friedlander et al., 1993), but a large body of work has focused on the ability of some mouse strain macrophages to generate a potently pro-inflammatory and rapid cell death called pyroptosis (further discussed below; Hanna et al., 1993; Bergsbaken et al., 2009). For the purposes of this review, macrophages that undergo pyroptosis are referred to as LT-sensitive and macrophages that experience a slow apoptotic death are referred to as LT-resistant. Interestingly, mice that have LT-sensitive macrophages are generally resistant to anthrax spore infections and those strains that succumb to anthrax tend to have LT-resistant macrophages (Welkos et al., 1986). This sensitivity is due to several genetic factors, but the majority of research has focused the allelic variants of Nalp1b/Nlrp1b (Boyden and Dietrich, 2006). Yet, there are exceptions to this correlation between Nlrplb-sensitive mice and rapid death due to purified LT injection; e.g., $\mathrm{C} 3 \mathrm{H}$ mice macrophages rapidly lyse when exposed to high concentrations of purified LT, but the mice have greater survival after LT injection than the LTsensitive Balb/c strain (Moayeri et al., 2004). These exceptions suggest that there may be several loci that confer lethality to the host, but the Nalp1b-sensitive allele is sufficient for macrophage pyroptosis (McAllister et al., 2003; Moayeri et al., 2004). Indeed, there is some data that pyroptosis by itself may have host protective effects. Transgenic mice that have an LT-sensitive Nalp1b allele in an otherwise resistant background have a greater resistance to spore challenge than the parental LT-resistant Nalp1b mouse strain and have greater recruitment of neutrophils into the peritoneal cavity during a peritoneal infection (Terra et al., 2010). Therefore, mice with the LT-sensitive Nalp1b allele have a greater early pro-inflammatory response due to LT intoxication, suggesting that an increased pro-inflammatory response is protective against $B$. anthracis infection. Similar findings support that this Nalp1b-sensitive protection is linked to neutrophil recruitment in a subcutaneous infection model (Moayeri et al., 2010). Finally, pyroptosis in response to purified LT exposure has only been reported in macrophages and DCs of mouse and rat strains (Roberts et al., 1998; Alileche et al., 2005); therefore, the role of Nlrp1b in human pathogenesis is unclear. At lower doses (or higher doses for non-sensitive strains/organisms) purified LT induces apoptosis in macrophages and DCs (Park et al., 2002; Popov et al., 2002; Alileche et al., 2005; Reig et al., 2008). To date, only Voth et al. (2005) have reported ET to be directly cytotoxic to both zebrafish embryos and RAW264.7 macrophage-like cells. However, ET inhibits cell cycle progression in the J774.1A and RAW264.7 macrophage-like cell line (Larabee et al., 2008; Gray and Hewlett, 2010). It is unknown if this delay leads to apoptosis or whether it is unique to macrophages.

\section{CARDIOVASCULAR EFFECTS HYPOXIA VS. SEPTIC SHOCK}

Systemic anthrax has long been known to affect the cardiovascular system and lead to cyanosis as well as large decreases in pulse and blood pressure in the final stages of infection in many animal models and human case studies (Cui et al., 2004, 2007; Klempner et al., 2010; Sweeney et al., 2010). What has become clearer is that the exotoxins not only target the vasculature, but also the cardiac tissue. Early anthrax research suggested that the exotoxin induced immunopathology due to sepsis and this led to the vascular damage and shock at terminal stages. In the past 10 years, however, there has been growing credence to the hypothesis that the shock-like phenotype of anthrax is due to cardiovascular damage directly from exotoxins rather than immunopathology from intoxicated host-cells. Injection of purified LT in mice leads to host tissue damage more consistent with hypoxia, rather than endotoxin/macrophage induced septic shock (Moayeri et al., 2003). Post-mortem histology from LT-injected BALB/cJ mice demonstrates a lack of indicators of cytokine-induced shock, e.g., fibrin clots and capillary thrombosis in the liver, kidney dysfunction, or extended increased production of pro-inflammatory cytokines. Rather, hypoxic response proteins rapidly increase after LT injection. This contrasted earlier work from Hanna and Collier which concluded that the rapid death from LT injection was due to increased cytokine production from macrophages (Hanna et al., 1993). Further, depletion of macrophages and antibody mediated neutralization of IL-1 protects mice from LT-mediated death. Adoptive transfer of RAW264.7 cells, which are sensitive to LTmediated pyroptosis and secrete IL- $1 \beta$, into macrophage-depleted mice re-establishes the rapid death phenotype (Hanna et al., 1993). Subsequent studies, however, have shown evidence that LT predominantly suppresses pro-inflammatory cytokine production even when LPS is used as the stimulus (Pellizzari et al., 1999; Cui et al., 2004, 2006). Similarly, slow infusion of LT into rats reduces cytokines in serum when compared to rats that received LPS only. Delivery of purified ET can also exert pro-inflammatory effects with some cytokines, but since ET does not induce pyroptosis, it has never been implicated as causing pro-inflammatory septic shock (Firoved et al., 2005).

Infusions or boluses of purified exotoxin do not completely replicate the pathology of anthrax and toxemia should not be thought of as recapitulating the bacterial infection. In contrast to the Moayeri hypoxia study, necropsies from B. anthracis infections show fibrin deposits and vasculitis in several animal models (Twenhafel, 2010). What is striking is that the bacilli can reach such high numbers in hosts before there are any overt signs of morbidity. Since the majority of data support an anti-inflammatory role of LT and ET, it is possible that anthrax exotoxins are temporarily reducing immunopathology by reducing the amount of proinflammatory cytokines produced by the host. Similar to the effect of anthrax exotoxin reducing the amount of pro-inflammatory cytokines in immune cells, several reports have shown that LT reduces pro-inflammatory cytokines in endothelial cells. IL-8 transcripts are destabilized by LT via dephosphorylation of the RNA 
regulation protein tristetraprolin (Batty et al., 2006; Chow et al., 2010). In addition, purified LT suppresses tissue factor production and NF- $\mathrm{B}$ upregulation when endothelial cells are stimulated by LPS (Rao et al., 2004). Perhaps the reduction of the inflammatory response is critical early in infection to protect the bacteria from innate defenses as they initially colonize and then progress toward dissemination to the blood stream. Although few studies have looked at the effect of B. anthracis peptidoglycan on host-cells, the pro-inflammatory responses induced by peptidoglycan require the p38 MAP kinase pathway that are in turn inhibited by purified LT (Langer et al., 2008; Iyer et al., 2010). Additionally, sub-lethal doses of LT can result in slight reductions of pro-inflammatory cytokines in rats injected with E. coli or its purified LPS (Cui et al., 2006). In contrast to the anti-inflammatory role of LT to the endothelium, LT has an additive effect with TNF- $\alpha$ to up regulate VCAM expression in human endothelial cells (Steele et al., 2005). Further studies are necessary to understand the mechanism and limitations of exotoxin to prevent immunopathology via peptidoglycan.

\section{EFFECTS ON VASCULATURE}

Although the exotoxins decrease host immunopathology at some stages of infection, there is evidence that LT and ET induce damage to the vasculature and increase permeability. Increased leakage or hemorrhage of the vasculature is commonly associated with anthrax in non-human primate models (Twenhafel, 2010). Treatment of primary human endothelial monolayers with purified LT, but not its individual components, increases the permeability in a concentration and time dependent manner (Warfel et al., 2005). Microscopic analysis further shows cell elongation, interepithelial gaps, and a reduction of surface vascular endothelial cadherins. While there is a small decrease in cell metabolism and low levels of apoptosis at 48 and $72 \mathrm{~h}$ post-addition, this is not sufficient to cause the increased permeability seen with LT treatment. In agreement with this, treatment with a cocktail of MAP kinase inhibitors recapitulates the permeability defect. Another study found that addition of purified LT to human umbilical endothelial cells (HUVEC) induced significant amounts of apoptosis (Kirby, 2004).

A unique method of investigating the effect of injected purified LT on vasculature in vivo utilized transparent zebrafish embryos (Bolcome et al., 2008). This model allows visualization of the progressive endothelial permeability and cardiovascular dysfunction in real time. Enlargement of the cardiac chambers first occurs, followed by a rapid increase in vascular permeability and intersegmented vessel collapse. Later a narrowing of the outflow tract from the heart and pericardial edema results in a cessation of blood flow. Vascular collapse occurs with no signs of decreased cell proliferation and with little cell death. Endothelial growth, proliferation, and permeability are in part regulated by vascular endothelial growth factor (VEGF) and VEGF receptors (VEGFR). VEGFR inhibitors can partially abrogate the effects of LT on vascular permeability (Bolcome et al., 2008). Whether LT's effect on VEGF pathways is independent from MAPK pathways is unknown. Vascular leakage in mouse models show similar results using a Miles assay, which uses intravenously delivered Evan's blue dye to quantify macromolecular vascular leakage. Subcutaneous injection of purified LT leads to a rapid $(15-25 \mathrm{~min})$ and dose dependent response in mice (Gozes et al., 2006). This rapid response to LT suggests that vascular leakage is due to a transcription/translation independent event. The fact that ketotifen, a histamine inhibitor, can greatly reduce the amount of leakage lends credence to this idea, though it is uncertain via which mechanism or on which cell ketotifen is functioning. The ability and degree of leakage varies between inbred mice strains and has no correlation to strain susceptibility to LT-mediated death (Gozes et al., 2006). Therefore, LT-mediated death may be due both to vascular leakage and the host's response to the leakage. Moreover it is unknown how MEK cleavage by LT could lead to such a rapid response.

Lethal toxin and ET can also affect endosomal recycling pathways, which can result in vasculature leakage. LF and EF reduces both Notch receptor and surface protein levels of the Notch ligand Delta when endogenously expressed by a GAL4 promoter in Drosophila melanogaster (Guichard et al., 2010). Notch and Delta are members of the Notch signaling pathway, which has crucial roles in embryogenesis and cell to cell communication. EF also down regulates the production of Serrate, another Notch ligand. Both of these exotoxins target the recycling of the Delta ligand that is necessary for proper DE-cadherin expression at cell junctions. The decreased cadherin expression leads to reduced cell to cell contact and therefore increases permeability. EF interferes with the Rab11 and Sec15 complex, whereas LF targets only Sec15 vesicles. Sec15/Rab11 are also inhibited by ET and LT in human brain microendothelial cell lines (hBMEC), leading to a decrease in membrane cadherin expression. Transwell assays also demonstrated an increase in hBMEC permeability.

There is conflicting data on ET's role in inducing vascular leakage. Addition of purified ET induces transendothelial cell macroapertures (TEM) in HUVEC monolayers and their formation correlates with the increase in permeability. These TEMs are resealed by the host via Missing in Metastasis protein through actin polymerization, suggesting a complicated balance in the maintenance of endothelial integrity (Maddugoda et al., 2011). Conversely, Tessier et al. (2007) found that administration of purified ET to HUVECs increased transepithelial electrical resistance (TEER) and suggested that ET induced edema indirectly by increasing inflammatory lipid mediators in vivo. Furthermore, pharmacological inhibition of prostanoids, histamines, and neurokinins (which were postulated to induce histamine production) reduced edema formation via vascular leakage. The source of neurokinins is unknown, but it could come from immune cells, fibroblasts, endothelial, or quite intriguingly, sensory neurons.

Finally, host control of endothelial permeability has a very important role in regards to the blood brain barrier (BBB), which is composed of a single layer of brain microendothelial cells (BMEC). Anthrax is not commonly thought of as a disease that results in meningitis; yet, data has shown that $\sim 50 \%$ of patients with systemic anthrax developed meningitis, far greater than many other bacterial causes (Abramova et al., 1993). B. anthracis is able to adhere to and be internalized by the BMEC and this invasion is potentiated by the presence of the exotoxin encoding genes. Additionally, infection in a meningitis model leads to inflamed and thickened meninges in $63 \%$ of infected mice (van Sorge et al., 2008). Further, adherence and invasion is aided by both bacterial exotoxins and the adhesin BslA. ZO- ${ }^{+}$tight junctions in BMEC 
monolayers exposed to non-encapsulated Sterne strains are disrupted to a greater extent than either the $\Delta b s l A$ mutant or the $\Delta \mathrm{ET} / \mathrm{LT}$ mutant (Ebrahimi et al., 2009). Infections with exotoxin deficient bacterial strains demonstrate that ET is necessary to disrupt the barrier function in BMEC monolayers, but LT is necessary for invasion. In vivo meningitis models of CD-1 mice show that LT is necessary for bacteria to reach the brain; however, it could be that the LT deficient strain is attenuated and cannot establish a productive infection in these mice.

\section{EFFECTS ON CARDIAC TISSUE}

There is also evidence that anthrax exotoxins cause early cellular cardiac damage that leads to later physiologic dysfunctions. Nitric oxide (NO) has crucial and pleiotropic roles in vasculature control and its production is targeted by LT. Of the three major isoforms of nitric oxide synthases, only neuronal nitric oxide synthase (nNOS) demonstrates a decrease in survival between $\mathrm{nNOS}^{-1-}$ mice and their wild type (WT) control when injected with purified LT (Moayeri et al., 2009). Further, cardiac tissue from nNOS ${ }^{-1-}$ mice has vacuoles between fibers of the tissue and suggestions of mitochondrial damage. Ultrastructure analysis indicate damage in both the $\mathrm{nNOS}^{-1-}$ and, at later time points, the WT mice. Additionally, cardiac tissue from both $\mathrm{nNOS}^{-1-}$ and their WT controls have grossly elevated levels of cardiac injury markers c-TroponinI, myoglobin, and heart-type fatty acid binding protein. One of the protective roles of nNOS is to scavenge reactive oxygen species (ROS) produced in cardiac tissues when stressed. Presence of ROS reduces the contractility of myocytes via reduction of response to $\mathrm{Ca}^{2+}$ stimulus (Akki et al., 2009). nNOS is thought to suppress superoxide generation by negatively regulating xanthine oxidoreductase (XOR), but treatment with allopurinol, a XOR inhibitor, exacerbates death versus controls (Khan et al., 2004; Moayeri et al., 2009). A later paper, however, reported that in vitro myocytes had an increase in superoxide production when treated with LT. Moreover, suppressing NADPH oxidase activity with the inhibitor apocynin largely suppresses the decreased contractility caused by LT (Kandadi et al., 2010). Therefore it is tempting to speculate that nNOS may have a role in suppressing LT-induced NADPH oxidase activity. ET also leads to damage in cardiac tissues. Histologically, ET-treated mice have cardiac lesions, myocyte degeneration, and increased separation of myofibers. This eventually leads to areas of necrosis (Firoved et al., 2005).

Given the damage that LT and ET directly cause on the heart, there is little wonder that they also cause decreased cardiac output. Purified LT injection has been shown to cause hypotension, bradycardia, and decrease the left ventricle ejection fraction (LVEF; Moayeri et al., 2009; Sweeney et al., 2010). Moreover, delivering LT induces an increase in the systolic and diastolic areas (Watson et al., 2007a,b). Purified ET was noted to quickly induce hypotension and tachycardia in both rats and canines. Intriguingly, injecting recombinant ET does not increase hemoglobin or pleural fluid concentrations in the heart, suggesting that the decreased output of the heart is not due to edema (Hicks et al., 2011). The purified exotoxins are synergistic when administered together, leading to a decrease in central venous pressure, an increase in heart rate, and decreased LVEF. Similar results were also seen in the rat model (Cui et al., 2007).

\section{ENDOCRINE SYSTEM EFFECTS}

Host inflammation and hormones are closely connected by regulatory circuits as a mechanism to quickly modulate the immune system. Of particular interest has been the hypothalamus-pituitaryadrenal (HPA) axis which releases glucocorticoids (GCs) into the blood stream in response to bacterial and viral infections, general toxic exposure, and pro-inflammatory cytokines (For review, see Webster and Sternberg, 2004). GCs signal through glucocorticoid receptors (GR) to inhibit NF- $\kappa$ B and AP-1 transcription, leading to decreased immune activation. Purified LT is a non-competitive inhibitor of GR activation in both in vitro and in vivo assays (Webster et al., 2003; Moayeri et al., 2005). Only treatment with p38 MAPK inhibitors led to a similar reduction in GR activation, suggesting the effect is due to LT's inhibition of the p38 pathway. Furthermore, similar repression could be seen with other nuclear hormones depending on whether the assay focused on the simple hormone promoters or the complex mouse mammary tumor virus promoter. Interestingly, LT's effect on GRs prevents gene activation, but does not affect gene repression (Webster and Sternberg, 2005).

Glucocorticoids are produced in the adrenal glands upon stimulation by adrenocorticotrophin. The nascent glucocorticoids are then able to act directly on the pituitary gland and hypothalamus to down regulate their production of hormones via a negative feedback loop (Webster and Sternberg, 2004). Mice that have undergone adrenalectomies (ADX), and therefore are deficient in GCs, have greater sensitivity to purified LT-mediated death than their control counterparts and have decreased GR-regulated gene activation in vivo (Moayeri et al., 2005). This occurs in both LT-sensitive BALB/cJ and LT-resistant DBA/2J mice. Since ADX DBA/2J mice have greater sensitivity to LT, it implies this lethality is due to a genetic locus distinct from Nalplb. Macrophages from ADX mice also have similar sensitivity/resistance profiles as control mice with intact GC signaling, further suggesting that Nalp1b alleles are not involved with the increased sensitivity to LT injection elicited by endocrine alteration. In addition to reducing GC production by $\mathrm{ADX}$, GRs can be pharmacologically blocked by a competitive inhibitor, RU486. BALB/cJ, but not DBA/2J, mice that are pretreated with RU486 are more sensitive to death from purified LT. It should be noted that BALB/cJ mice are hyper-GC producers and produce pro-inflammatory cytokines in response to LT due to pyroptosis. Therefore, it could be that BALB/cJ mice are more sensitive to RU486 pretreatment because the inhibitor prevents GC from dampening the pyroptotic response to LT, exacerbating the effect of pro-inflammatory cytokines. DBA/2J mice are hypo-GC producers and therefore produce very low amounts of GC in response to purified LT intoxication. Since RU486 is a competitive inhibitor for GRs and DBA/2J mice produce low amounts of corticosterone, only a slight effect would be seen with this inhibitor (Moayeri et al., 2005).

Purified LT injection also induces four to five times greater levels of an endogenous GC, corticosterone, in BALB/cJ mice but not DBA/2J mice (Moayeri et al., 2005). This suggests that, at least for these strains, higher GC levels correlate with LT-sensitive strains. Additionally, treatment of either ADX or control DBA/2J mice with dexamethasone (a synthetic GC) also exacerbates LTmediated death (Moayeri et al., 2005). This further suggests that LT 
does not inhibit GR-mediated gene activation at the ligand binding level. The authors speculate that dexamethasone may increase susceptibility through altering the quantity or activity of GRs, or HPA-independent mechanisms; such as working synergistically with LT to inhibit p38 or other MEKs, modulating GC's effects on vasculature tone, or changing regulation of the hypoxic response. Moreover, the fact that both ADX and exogenous GC supplementation lead to greater sensitivity to LT-mediated death may suggest that disturbing the HPA axis by ADX or addition of GCs occur by unique mechanisms.

Lastly, pretreatment with either purified LT or ET sensitizes DBA/2J mice to purified LT-mediated death (Moayeri et al., 2005; Firoved et al., 2007). It is not known if the sensitization caused by pretreatment with LT is elicited by the same mechanisms that occur after ADX. The authors speculated that there may be an optimal number of GRs that need to be activated for protection from LT injection. ET has been shown to increase corticosterone serum levels in DBA/2J mice, which may lead to the increase in LT sensitivity.

\section{NEUROLOGICAL EFFECTS}

Little work has focused on the effects of anthrax exotoxins on the nervous system, despite the ability of $B$. anthracis to cause meningitis and the role the sympathetic nervous system plays in vascular homeostasis. Purified mixtures of LT and ET can rapidly cross the BBB and cause changes in subcortical electroencephelograms (EEGs) in as little as 30-60s in Rhesus macaques and chimpanzees (Vick et al., 1968). Additionally, the anthrax exotoxins can induce coma or semi-consciousness between 5 and 10 min post-inoculation and elicit rapid changes to the nerve impulses in the heart in about $1 \mathrm{~h}$. Interestingly, the EEGs suggest that exotoxin is able to affect unique areas of the brain over time. Cortical and subcortical EEGs show rapid changes occurring as soon as 5 min after toxin injection. Cortical EEGs, which represent higher brain functions, indicate a cessation of activity approximately $12 \mathrm{~h}$ sooner than subcortical EEGs that measure lower brain functions. Therefore, while the host may be comatose early after injection, vital functions such as respiration and cardiac activity are still maintained. The loss of activity with the subcortical EEG corresponds with decreasing phrenic nerve discharge, a respiratory stimulus, and an ECG that suggests cardiac ischema (Vick et al., 1968). Similar effects occur when Rhesus macaques are challenged with B. anthracis Vollum spores (Klein et al., 1968). Since these experiments, there have been few publications in this area until a recent study that investigated the role of LT on the sympathetic nervous system. The sympathetic nervous system has a role in regulating blood pressure using specialized neurons called baroreceptors. Sprague-Dawley rats with either intact baroreceptors or denervated baroreceptors were given an infusion of LT and both had activation of the sympathetic nervous system, blood pressure, and heart rate within minutes of exotoxin delivery. However, denervated rats had higher levels of nerve activation, blood pressure, and heart rate. The peak of sympathetic nerve discharge occurred after the peak increase in blood pressure, suggesting that nerve discharge is not the cause of the hypotension (Garcia et al., 2012).

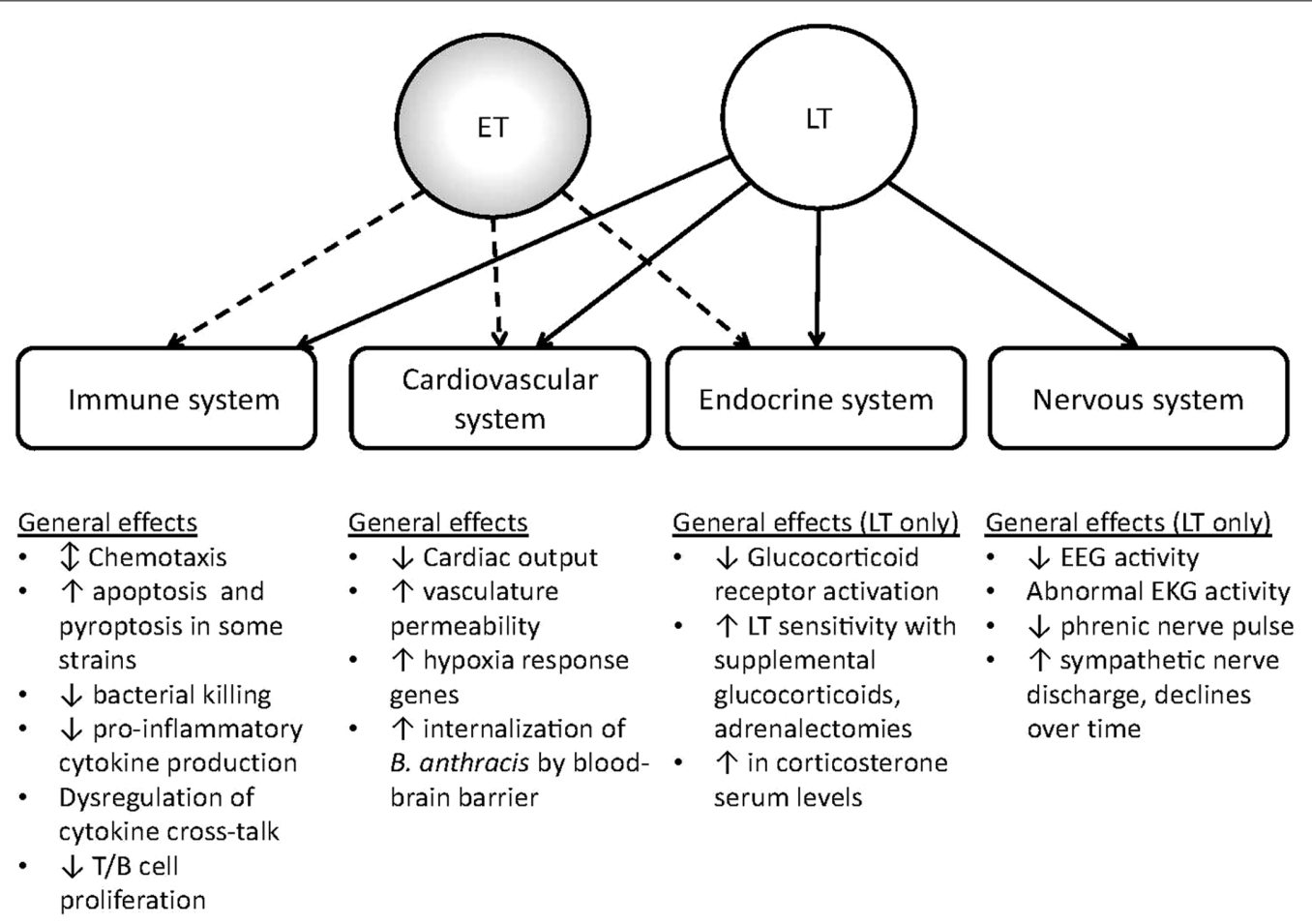

FIGURE 1 | General effects of edema toxin and lethal toxin on host physiology. Lethal toxin can alter host responses in the immune, cardiovascular, endocrine, and nervous system. At present, edema toxin has known effects on the host cardiovascular, endocrine, and immune system. 


\section{SUMMARY AND FUTURE DIRECTIONS}

The exotoxins of $B$. anthracis were first discovered by examining their physiological effects in animal models. Before the exotoxin proteins were identified, Smith et al. reported that filtered plasma from $B$. anthracis infected guinea pigs contained a "lethal factor" and an "edema producing factor" (Smith and Keppie, 1954). Smith and Keppie could not have known in the 1960s that the exotoxins target critical and well conserved pathways that are present in most cells, which lead to diverse effects throughout the host (Figure 1). Recent and current studies are just now beginning to elucidate which of these systems are ultimately important for the progression of and protection from B. anthracis. However, most of these studies focus on the effect of LT on the host. Future work may be able to determine what roles ET might have on similar systems. Additionally, though several studies have measured amounts of exotoxin in animal models, these studies have tended to detect relatively high concentrations of exotoxin $(10-100 \mathrm{ng} / \mathrm{mL})$, typically only looked in the serum, and in one case could only detect PA at late stages of infection (Kobiler et al., 2006; Mabry et al., 2006; Tang et al., 2009). More sensitive enzymatic assays could be employed to investigate exotoxin concentrations at the earliest time points that enable dissemination, establishment of infection, and the location

\section{REFERENCES}

Abrami, L., Lindsay, M., Parton, R. G., Leppla, S. H., and Van Der Goot, F. G. (2004). Membrane insertion of anthrax protective antigen and cytoplasmic delivery of lethal factor occur at different stages of the endocytic pathway. J. Cell Biol. 166, 645-651.

Abrami, L., Liu, S., Cosson, P., Leppla, S. H., and Van Der Goot, F. G. (2003). Anthrax toxin triggers endocytosis of its receptor via a lipid raft-mediated clathrindependent process. J. Cell Biol. 160, 321-328.

Abramova, F. A., Grinberg, L. M., Yampolskaya, O. V., and Walker, D. H. (1993). Pathology of inhalational anthrax in 42 cases from the Sverdlovsk outbreak of 1979. Proc. Natl. Acad. Sci. U.S.A. 90, 2291-2294.

Agrawal, A., Lingappa, J., Leppla, S. H., Agrawal, S., Jabbar, A., Quinn, C., and Pulendran, B. (2003). Impairment of dendritic cells and adaptive immunity by anthrax lethal toxin. Nature 424, 329-334.

Akki, A., Zhang, M., Murdoch, C., Brewer, A., and Shah, A. M. (2009). NADPH oxidase signaling and cardiac myocyte function. J. Mol. Cell. Cardiol. 47, 15-22.

Alileche, A., Serfass, E. R., Muehlbauer, S. M., Porcelli, S. A., and Brojatsch, J. (2005). Anthrax lethal toxin-mediated killing of human and murine dendritic cells impairs the adaptive immune response. PLoS Pathog. 1, e19. doi:10.1371/journal.ppat.0010019

Baldari, C. T., Tonello, F., Paccani, S. R., and Montecucco, C. (2006). Anthrax toxins: a paradigm of bacterial immune suppression. Trends Immunol. 27, 434-440.

Banchereau, J., Briere, F., Caux, C., Davoust, J., Lebecque, S., Liu, Y. J., Pulendran, B., and Palucka, K. (2000). Immunobiology of dendritic cells. Annu. Rev. Immunol. 18, 767-811.

Barson, H. V., Mollenkopf, H., Kaufmann, S. H., and Rijpkema, S. (2008). Anthrax lethal toxin suppresses chemokine production in human neutrophil NB-4 cells. Biochem. Biophys. Res. Commun. 374, 288-293.

Batty, S., Chow, E. M., Kassam, A., Der, S. D., and Mogridge, J. (2006). Inhibition of mitogen-activated protein kinase signalling by Bacillus anthracis lethal toxin causes destabilization of interleukin8 mRNA. Cell. Microbiol. 8, 130-138.

Bergsbaken, T., Fink, S. L., and Cookson, B. T. (2009). Pyroptosis: host cell death and inflammation. Nat. Rev. Microbiol. 7, 99-109.

Bolcome, R. E. III, Sullivan, S. E., Zeller, R., Barker, A. P., Collier, R. J., and Chan, J. (2008). Anthrax lethal toxin

and concentration of exotoxin in particular organs. Perhaps this data could also lead to a better understanding of primary and secondary effects of intoxication on an organ system. For example, does increased vasculature permeability precede cardiac dysfunction? Lastly, it is important to keep in mind that toxemia is only one part of anthrax and care should be taken to not over extrapolate results derived from the use of purified exotoxins. For example, LT may rapidly kill rats, but there are key differences between the exotoxin-mediated death and the bacterial disease, such as, vasculitis. Moreover, does the exotoxin prevent immune damage to the vasculature from high levels of peptidoglycan when the host is bacteremic? Hopefully, future studies will better define the effects of the exotoxin and the bacteria on the physiology of the host. Understanding how the exotoxins are able to subvert these systems at a physiological level not only clarifies the roles of exotoxins in infection, but better defines how the host systems interact with each other in pathogenic and homeostatic scenarios.

\section{ACKNOWLEDGMENTS}

We wish to acknowledge funding from the Biodefense Research Training and Career Development grant (5T32AI055432-09).

induces cell death-independent permeability in zebrafish vasculature. Proc. Natl. Acad. Sci. U.S.A. 105, 2439-2444.

Bonuccelli, G., Sotgia, F., Frank, P. G., Williams, T. M., De Almeida, C. J., Tanowitz, H. B., Scherer, P. E., Hotchkiss, K. A., Terman, B. I., Rollman, B., Alileche, A., Brojatsch, J., and Lisanti, M. P. (2005). ATR/TEM8 is highly expressed in epithelial cells lining Bacillus anthracis' three sites of entry: implications for the pathogenesis of anthrax infection. Am. J. Physiol. Cell Physiol. 288, C1402-C1410.

Boyden, E. D., and Dietrich, W. F. (2006). Nalplb controls mouse macrophage susceptibility to anthrax lethal toxin. Nat. Genet. 38, 240-244.

Bradley, K. A., Mogridge, J., Mourez, M., Collier, R. J., and Young, J. A. (2001). Identification of the cellular receptor for anthrax toxin. Nature 414, 225-229.

Brittingham, K. C., Ruthel, G., Panchal, R. G., Fuller, C. L., Ribot, W. J., Hoover, T. A., Young, H. A., Anderson, A. O., and Bavari, S. (2005). Dendritic cells endocytose Bacillus anthracis spores: implications for anthrax pathogenesis. J. Immunol. 174, 5545-5552.

Chand, H. S., Drysdale, M., Lovchik, J., Koehler, T. M., Lipscomb, M. F., and Lyons, C. R. (2009). Discriminating virulence mechanisms among Bacillus anthracis strains by using a murine subcutaneous infection model. Infect. Immun. 77, 429-435.

Chow, E. M., Batty, S., and Mogridge, J. (2010). Anthrax lethal toxin promotes dephosphorylation of TTP and formation of processing bodies. Cell. Microbiol. 12, 557-568.

Cleret, A., Quesnel-Hellmann, A., Mathieu, J., Vidal, D., and Tournier, J. N. (2006). Resident CD11c+ lung cells are impaired by anthrax toxins after spore infection. J. Infect. Dis. 194, 86-94.

Comer, J. E., Chopra, A. K., Peterson, J. W., and Konig, R. (2005). Direct inhibition of T-lymphocyte activation by anthrax toxins in vivo. Infect. Immun. 73, 8275-8281.

Cote, C. K., Dimezzo, T. L., Banks, D. J., France, B., Bradley, K. A., and Welkos, S. L. (2008). Early interactions between fully virulent Bacillus anthracis and macrophages that influence the balance between spore clearance and development of a lethal infection. Microbes Infect. 10, 613-619.

Cote, C. K., Rea, K. M., Norris, S. L., Van Rooijen, N., and Welkos, S. L. (2004). The use of a model of in vivo macrophage depletion to study the role of macrophages during infection with Bacillus anthracis spores. Microb. Pathog. 37, 169-175. 
Cote, C. K., Van Rooijen, N., and Welkos, S. L. (2006). Roles of macrophages and neutrophils in the early host response to Bacillus anthracis spores in a mouse model of infection. Infect. Immun. 74, 469-480.

Crawford, M. A., Aylott, C. V., Bourdeau, R. W., and Bokoch, G. M. (2006). Bacillus anthracis toxins inhibit human neutrophil NADPH oxidase activity. J. Immunol. 176, 7557-7565.

Cui, X., Li, Y., Li, X., Haley, M., Moayeri, M., Fitz, Y., Leppla, S. H., and Eichacker, P. Q. (2006). Sublethal doses of Bacillus anthracis lethal toxin inhibit inflammation with lipopolysaccharide and Escherichia coli challenge but have opposite effects on survival. J. Infect. Dis. 193, 829-840.

Cui, X., Li, Y., Li, X., Laird, M. W., Subramanian, M., Moayeri, M., Leppla, S. H., Fitz, Y., Su, J., Sherer, K., and Eichacker, P. Q. (2007). Bacillus anthracis edema and lethal toxin have different hemodynamic effects but function together to worsen shock and outcome in a rat model. $J$. Infect. Dis. 195, 572-580.

Cui, X., Moayeri, M., Li, Y., Li, X., Haley, M., Fitz, Y., Correa-Araujo, R., Banks, S. M., Leppla, S. H., and Eichacker, P. Q. (2004). Lethality during continuous anthrax lethal toxin infusion is associated with circulatory shock but not inflammatory cytokine or nitric oxide release in rats. Am. J. Physiol. Regul. Integr. Comp. Physiol. 286, R699-R709.

Dal Molin, F., Tonello, F., Ladant, D., Zornetta, I., Zamparo, I., Di Benedetto, G., Zaccolo, M., and Montecucco, C. (2006). Cell entry and cAMP imaging of anthrax edema toxin. EMBO J. 25, 5405-5413.

Dixon, T. C., Fadl, A. A., Koehler, T. M., Swanson, J. A., and Hanna, P. C. (2000). Early Bacillus anthracismacrophage interactions: intracellular survival and escape. Cell. Microbiol. 2, 453-463.

Duesbery, N., Woude, V., Webb, C., and Klimpel, K. (1998). Proteolytic inactivation of MAP-kinase-kinase by anthrax lethal factor. Science 280, 734-737.

During, R. L., Li, W., Hao, B., Koenig, J. M., Stephens, D. S., Quinn, C. P., and Southwick, F. S. (2005). Anthrax lethal toxin paralyzes neutrophil actin-based motility. J. Infect. Dis. 192, 837-845.

Ebrahimi, C. M., Kern, J. W., Sheen, T. R., Ebrahimi-Fardooee, M. A., Van Sorge, N. M., Schneewind, O., and Doran, K. S. (2009). Penetration of the blood-brain barrier by Bacillus anthracis requires the pXO1encoded BslA protein. J. Bacteriol. 191, 7165-7173.

Erwin, J. L., Dasilva, L. M., Bavari, S., Little, S. F., Friedlander, A. M., and Chanh, T. C. (2001). Macrophagederived cell lines do not express proinflammatory cytokines after exposure to Bacillus anthracis lethal toxin. Infect. Immun. 69, 1175-1177.

Ezzell, J. W. Jr., and Abshire, T. G. (1992). Serum protease cleavage of Bacillus anthracis protective antigen. J. Gen. Microbiol. 138, 543-549.

Fang, H., Xu, L., Chen, T. Y., Cyr, J. M., and Frucht, D. M. (2006). Anthrax lethal toxin has direct and potent inhibitory effects on B cell proliferation and immunoglobulin production. J. Immunol. 176, 6155-6161.

Firoved, A. M., Miller, G. F., Moayeri, M., Kakkar, R., Shen, Y., Wiggins, J. F., Mcnally, E. M., Tang, W. J., and Leppla, S. H. (2005). Bacillus anthracis edema toxin causes extensive tissue lesions and rapid lethality in mice. Am. J. Pathol. 167, 1309-1320.

Firoved, A. M., Moayeri, M., Wiggins, J. F., Shen, Y., Tang, W. J., and Leppla, S. H. (2007). Anthrax edema toxin sensitizes DBA/2J mice to lethal toxin. Infect. Immun. 75, 2120-2125.

Friedlander, A. M. (1986). Macrophages are sensitive to anthrax lethal toxin through an acid-dependent process. J. Biol. Chem. 261, 7123-7126.

Friedlander, A. M., Bhatnagar, R., Leppla, S. H., Johnson, L., and Singh, Y. (1993). Characterization of macrophage sensitivity and resistance to anthrax lethal toxin. Infect. Immun. 61, 245-252.

Galgani, M., De Rosa, V., De Simone, S., Leonardi, A., D’Oro, U., Napolitani, G., Masci, A. M., Zappacosta, S., and Racioppi, L. (2004). Cyclic AMP modulates the functional plasticity of immature dendritic cells by inhibiting Src-like kinases through protein kinase A-mediated signaling. J. Biol. Chem. 279, 32507-32514

Garcia, A. A., Fels, R. J., Mosher, L. J., and Kenney, M. J. (2012). Bacillus anthracis lethal toxin alters regulation of visceral sympathetic nerve discharge. J. Appl. Physiol. 112, 1033-1040.

Glomski, I. J., Fritz, J. H., Keppler, S. J., Balloy, V., Chignard, M., Mock, M., and Goossens, P. L. (2007). Murine splenocytes produce inflammatory cytokines in a MyD88-dependent response to Bacillus anthracis spores. Cell. Microbiol. 9, 502-513.

Gonzales, C. M., Williams, C. B., Calderon, V. E., Huante, M. B. Moen, S. T., Popov, V. L., Baze, W.
B., Peterson, J. W., and Endsley, J. J. (2012). Antibacterial role for natural killer cells in host defense to Bacillus anthracis. Infect. Immun. 80, 234-242.

Gordon, V. M., Klimpel, K. R., Arora, N., Henderson, M. A., and Leppla, S. H. (1995). Proteolytic activation of bacterial toxins by eukaryotic cells is performed by furin and by additional cellular proteases. Infect. Immun. 63, 82-87.

Gozes, Y., Moayeri, M., Wiggins, J. F., and Leppla, S. H. (2006). Anthrax lethal toxin induces ketotifen-sensitive intradermal vascular leakage in certain inbred mice. Infect. Immun. 74 1266-1272.

Gray, M. C., and Hewlett, E. L. (2010). Cell cycle arrest induced by the bacterial adenylate cyclase toxins from Bacillus anthracis and Bordetella pertussis. Cell. Microbiol. 13, 123-134.

Green, B. D., Battisti, L., Koehler, T. M. Thorne, C. B., and Ivins, B. E. (1985). Demonstration of a capsule plasmid in Bacillus anthracis. Infect. Immun. 49, 291-297.

Guichard, A., Mcgillivray, S. M., CruzMoreno, B., Van Sorge, N. M., Nizet, V., and Bier, E. (2010). Anthrax toxins cooperatively inhibit endocytic recycling by the Rab11/Sec15 exocyst. Nature 467, 854-858.

Guidi-Rontani, C. (2002). The alveolar macrophage: the Trojan horse of Bacillus anthracis. Trends Microbiol. 10, 405-409.

Ha, S. D., Ham, B., Mogridge, J., Saftig, P., Lin, S., and Kim, S. O. (2010). Cathepsin B-mediated autophagy flux facilitates the anthrax toxin receptor 2-mediated delivery of anthrax lethal factor into the cytoplasm. J. Biol. Chem. 285 , 2120-2129.

Hamerman, J. A., Ogasawara, K., and Lanier, L. L. (2004). Cutting edge: toll-like receptor signaling in macrophages induces ligands for the NKG2D receptor. J. Immunol. 172, 2001-2005.

Hanna, P. C., Acosta, D., and Collier, R. J. (1993). On the role of macrophages in anthrax. Proc. Natl. Acad. Sci. U.S.A. 90, 10198-10201.

Heninger, S., Drysdale, M., Lovchik, J. Hutt, J., Lipscomb, M. F., Koehler, T. M., and Lyons, C. R. (2006). Toxin-deficient mutants of Bacillus anthracis are lethal in a murine model for pulmonary anthrax. Infect. Immun. 74, 6067-6074.

Hicks, C. W., Li, Y., Okugawa, S., Solomon, S. B., Moayeri, M., Leppla, S. H., Mohanty, A., Subramanian, G. M., Mignone, T. S., Fitz, Y., Cui, X., and Eichacker, P. Q. (2011). Anthrax edema toxin has cAMP-mediated stimulatory effects and high-dose lethal toxin has depressant effects in an isolated perfused rat heart model. Am. J. Physiol. Heart Circ. Physiol. 300, H1108-H1118.

Hong, J., Doebele, R. C., Lingen, M. W., Quilliam, L. A., Tang, W. J., and Rosner, M. R. (2007). Anthrax edema toxin inhibits endothelial cell chemotaxis via Epac and Rap1. J. Biol. Chem. 282, 19781-19787.

Hotchkiss, K. A., Basile, C. M., Spring, S. C., Bonuccelli, G., Lisanti, M. P., and Terman, B. I. (2005). TEM8 expression stimulates endothelial cell adhesion and migration by regulating cell-matrix interactions on collagen. Exp. Cell Res. 305, 133-144.

Ingram, R. J., Metan, G., Maillere, B. Doganay, M., Ozkul, Y., Kim, L. U., Baillie, L., Dyson, H., Williamson, E. D., Chu, K. K., Ascough, S., Moore, S., Huwar, T. B., Robinson, J. H., Sriskandan, S., and Altmann, D. M. (2010). Natural exposure to cutaneous anthrax gives long-lasting T cell immunity encompassing infection-specific epitopes. J. Immunol. 184, 3814-3821.

Iyer, J. K., Khurana, T., Langer, M., West, C. M., Ballard, J. D., Metcalf, J. P., Merkel, T. J., and Coggeshall, K. M. (2010). Inflammatory cytokine response to Bacillus anthracis peptidoglycan requires phagocytosis and lysosomal trafficking. Infect. Immun. 78, 2418-2428.

Joshi, S. K., Lang, G. A., Larabee, J. L., Devera, T. S., Aye, L. M., Shah, H. B., Ballard, J. D., and Lang, M. L. (2009). Bacillus anthracis lethal toxin disrupts TCR signaling in CD1d-restricted NKT cells leading to functional anergy. PLoS Pathog. 5, e1000588. doi:10.1371/journal.ppat.1000588

Kandadi, M. R., Hua, Y., Ma, H., Li, Q., Kuo, S. R., Frankel, A. E., and Ren, J. (2010). Anthrax lethal toxin suppresses murine cardiomyocyte contractile function and intracellular $\mathrm{Ca} 2+$ handling via a NADPH oxidase-dependent mechanism. PLoS ONE 5, e13335. doi:10.1371/journal.pone.0013335

Kassam, A., Der, S. D., and Mogridge, J. (2005). Differentiation of human monocytic cell lines confers susceptibility to Bacillus anthracis lethal toxin. Cell. Microbiol. 7, 281-292.

Kau, J. H., Sun, D. S., Huang, H. S., Lien, T. S., Huang, H. H., Lin, H. C., and Chang, H. H. (2010). Sublethal doses of anthrax lethal toxin on the suppression of macrophage phagocytosis. PLoS ONE 5, e14289. doi:10.1371/journal.pone.0014289 
Khan, S. A., Lee, K., Minhas, K. M., Gonzalez, D. R., Raju, S. V., Tejani, A. D., Li, D., Berkowitz, D. E., and Hare, J. M. (2004). Neuronal nitric oxide synthase negatively regulates xanthine oxidoreductase inhibition of cardiac excitation-contraction coupling. Proc. Natl. Acad. Sci. U.S.A. 101, 15944-15948.

Kim, C., Gajendran, N., Mittrucker, H. W., Weiwad, M., Song, Y. H., Hurwitz, R., Wilmanns, M., Fischer, G., and Kaufmann, S. H. (2005). Human alpha-defensins neutralize anthrax lethal toxin and protect against its fatal consequences. Proc. Natl. Acad. Sci. U.S.A. 102, 4830-4835.

Kim, C., Wilcox-Adelman, S., Sano, Y., Tang, W. J., Collier, R. J., and Park, J. M. (2008). Antiinflammatory cAMP signaling and cell migration genes co-opted by the anthrax bacillus. Proc. Natl. Acad. Sci. U.S.A. 105, 6150-6155.

Kintzer, A. F., Thoren, K. L., Sterling, H. J., Dong, K. C., Feld, G. K., Tang, Ii, Zhang, T. T., Williams, E. R., Berger, J. M., and Krantz, B. A. (2009). The protective antigen component of anthrax toxin forms functional octameric complexes. J. Mol. Biol. 392, 614-629.

Kirby, J. E. (2004). Anthrax lethal toxin induces human endothelial cell apoptosis. Infect. Immun. 72, 430-439.

Klein, F., Lincoln, R. E., Dobbs, J. P., Mahlandt, B. G., Remmele, N. S., and Walker, J. S. (1968). Neurological and physiological responses of the primate to anthrax infection. $J$. Infect. Dis. 118, 97-103.

Klempner, M. S., Talbot, E. A., Lee, S. I., Zaki, S., and Ferraro, M. J. (2010). Case records of the Massachusetts General Hospital. Case 25-2010. A 24-year-old woman with abdominal pain and shock. N. Engl. J. Med. 363, 766-777.

Klezovich-Bénard, M., Corre, J. P., Jusforgues-Saklani, H., Fiole, D., Burjek, N., Tournier, J. N., and Goossens, P. L. (2012). Mechanisms of NK cell-macrophage Bacillus anthracis crosstalk: a balance between stimulation by spores and differential disruption by toxins. PLoS Pathog. 8, e1002481. doi:10.1371/journal.ppat.1002481

Kobiler, D., Weiss, S., Levy, H., Fisher, M., Mechaly, A., Pass, A., and Altboum, Z. (2006). Protective antigen as a correlative marker for anthrax in animal models. Infect. Immun. 74, 5871-5876.

Lacy, D. B., Wigelsworth, D. J., Melnyk, R. A., Harrison, S. C., and Collier,
R. J. (2004). Structure of heptameric protective antigen bound to an anthrax toxin receptor: a role for receptor in $\mathrm{pH}$-dependent pore formation. Proc. Natl. Acad. Sci. U.S.A. 101, 13147-13151.

Langer, M., Malykhin, A., Maeda, K., Chakrabarty, K., Williamson, K. S., Feasley, C. L., West, C. M., Metcalf, J. P., and Coggeshall, K. M. (2008). Bacillus anthracis peptidoglycan stimulates an inflammatory response in monocytes through the p38 mitogen-activated protein kinase pathway. PLoS ONE 3, e3706. doi:10.1371/journal.pone.0003706

Larabee, J. L., Degiusti, K., Regens, J. L., and Ballard, J. D. (2008). Bacillus anthracis edema toxin activates nuclear glycogen synthase kinase 3beta. Infect. Immun. 76, 4895-4904.

Larabee, J. L., Maldonado-Arocho, F. J., Pacheco, S., France, B., Degiusti, K., Shakir, S. M., Bradley, K. A., and Ballard, J. D. (2011). Glycogen synthase kinase 3 activation is important for anthrax edema toxininduced dendritic cell maturation and anthrax toxin receptor 2 expression in macrophages. Infect. Immun. 79, 3302-3308.

Leppla, S. H. (1982). Anthrax toxin edema factor: a bacterial adenylate cyclase that increases cyclic AMP concentrations of eukaryotic cells. Proc. Natl. Acad. Sci. U.S.A. 79, 3162-3166.

Liu, S., Crown, D., Miller-Randolph, S., Moayeri, M., Wang, H., Hu, H., Morley, T., and Leppla, S. H. (2009). Capillary morphogenesis protein- 2 is the major receptor mediating lethality of anthrax toxin in vivo. Proc. Natl. Acad. Sci. U.S.A. 106, 12424-12429.

Liu, S., Miller-Randolph, S., Crown, D., Moayeri, M., Sastalla, I., Okugawa, S., and Leppla, S. H. (2010). Anthrax toxin targeting of myeloid cells through the CMG2 receptor is essential for establishment of Bacillus anthracis infections in mice. Cell Host Microbe 8, 455-462.

Mabry, R., Brasky, K., Geiger, R., Carrion, R. Jr., Hubbard, G. B., Leppla, S., Patterson, J. L., Georgiou, G., and Iverson, B. L. (2006). Detection of anthrax toxin in the serum of animals infected with Bacillus anthracis by using engineered immunoassays. Clin. Vaccine Immunol. 13, 671-677.

Maddugoda, M. P., Stefani, C., Gonzalez-Rodriguez, D., Saarikangas, J., Torrino, S., Janel, S., Munro, P., Doye, A., Prodon, F., AurrandLions, M., Goossens, P. L., Lafont, F., Bassereau, P., Lappalainen, P., Brochard, F., and Lemichez, E.
(2011). cAMP signaling by anthrax edema toxin induces transendothelial cell tunnels, which are resealed by MIM via Arp2/3-driven actin polymerization. Cell Host Microbe 10, 464-474.

Maldonado-Arocho, F. J., and Bradley, K. A. (2009). Anthrax edema toxin induces maturation of dendritic cells and enhances chemotaxis towards macrophage inflammatory protein 3beta. Infect. Immun. 77, 2036-2042.

Martchenko, M., Candille, S. I., Tang, H., and Cohen, S. N. (2012). Human genetic variation altering anthrax toxin sensitivity. Proc. Natl. Acad. Sci. U.S.A. 109, 2972-2977.

Martchenko, M., Jeong, S. Y., and Cohen, S. N. (2010). Heterodimeric integrin complexes containing beta1integrin promote internalization and lethality of anthrax toxin. Proc. Natl. Acad. Sci. U.S.A. 107, 15583-15588.

McAllister, R. D., Singh, Y., Du Bois, W. D., Potter, M., Boehm, T., Meeker, N. D., Fillmore, P. D., Anderson, L. M., Poynter, M. E., and Teuscher, C. (2003). Susceptibility to anthrax lethal toxin is controlled by three linked quantitative trait loci. Am. J. Pathol. 163, 1735-1741.

Mikesell, P., Ivins, B. E., Ristroph, J. D. and Dreier, T. M. (1983). Evidence for plasmid-mediated toxin production in Bacillus anthracis. Infect. Immun. 39, 371-376.

Milne, J. C., Furlong, D., Hanna, P. C., Wall, J. S., and Collier, R. J. (1994). Anthrax protective antigen forms oligomers during intoxication of mammalian cells. J. Biol. Chem. 269, 20607-20612.

Moayeri, M., Crown, D., Dorward, D. W., Gardner, D., Ward, J. M., Li, Y., Cui, X., Eichacker, P., and Leppla, S. H. (2009). The heart is an early target of anthrax lethal toxin in mice: a protective role for neuronal nitric oxide synthase (nNOS). PLoS Pathog. 5, el000456. doi:10.1371/journal.ppat.1000456

Moayeri, M., Crown, D., Newman, Z. L., Okugawa, S., Eckhaus, M., Cataisson, C., Liu, S., Sastalla, I., and Leppla, S. H. (2010). Inflammasome sensor Nlrplbdependent resistance to anthrax is mediated by caspase-1, IL-1 signaling and neutrophil recruitment. PLoS Pathog. 6, e1001222. doi:10.1371/journal.ppat.1001222

Moayeri, M., Haines, D., Young, H. A., and Leppla, S. H. (2003). Bacillus anthracis lethal toxin induces TNF-alpha-independent hypoxiamediated toxicity in mice. J. Clin. Invest. 112, 670-682.
Moayeri, M., and Leppla, S. H. (2011). "Anthrax toxins," in Bacillus Anthracis and Anthrax, ed. N. H. Bergman (Hoboken, NJ: John Wiley \& Sons, Inc.), 121-156.

Moayeri, M., Martinez, N. W., Wiggins, J., Young, H. A., and Leppla, S. H. (2004). Mouse susceptibility to anthrax lethal toxin is influenced by genetic factors in addition to those controlling macrophage sensitivity. Infect. Immun. 72, 4439-4447.

Moayeri, M., Webster, J. I., Wiggins, J. F., Leppla, S. H., and Sternberg, E. M. (2005). Endocrine perturbation increases susceptibility of mice to anthrax lethal toxin. Infect. Immun. 73, 4238-4244.

Moayeri, M., Wiggins, J. F., and Leppla, S. H. (2007). Anthrax protective antigen cleavage and clearance from the blood of mice and rats. Infect. Immun. 75, 5175-5184.

Mock, M., and Fouet, A. (2001). Anthrax. Annu. Rev. Microbiol. 55, 647-671.

Mogridge, J., Cunningham, K., and Collier, R. J. (2002a). Stoichiometry of anthrax toxin complexes. Biochemistry 41, 1079-1082.

Mogridge, J., Cunningham, K., Lacy, D. B., Mourez, M., and Collier, R. J. (2002b). The lethal and edema factors of anthrax toxin bind only to oligomeric forms of the protective antigen. Proc. Natl. Acad. Sci. U.S.A. 99, 7045-7048.

Nanda, A., Carson-Walter, E. B., Seaman, S., Barber, T. D., Stampfl, J. Singh, S., Vogelstein, B., Kinzler, K. W., and St Croix, B. (2004). TEM8 interacts with the cleaved C5 domain of collagen alpha $3(\mathrm{VI})$. Cancer Res. 64, 817-820.

O'Brien, J., Friedlander, A., Dreier, T. Ezzell, J., and Leppla, S. (1985). Effects of anthrax toxin components on human neutrophils. Infect. Immun. 47, 306-310.

Paccani, S. R., Benagiano, M., Savino, M. T., Finetti, F., Tonello, F., D’Elios, M. M., and Baldari, C. T. (2011). The adenylate cyclase toxin of Bacillus anthracis is a potent promoter of $\mathrm{T}(\mathrm{H}) 17$ cell development. J. Allergy Clin. Immunol. 127, 1635-1637.

Paccani, S. R., Tonello, F., Ghittoni, R., Natale, M., Muraro, L., D'Elios, M. M., Tang, W. J., Montecucco, C., and Baldari, C. T. (2005). Anthrax toxins suppress $\mathrm{T}$ lymphocyte activation by disrupting antigen receptor signaling. J. Exp. Med. 201, 325-331.

Park, J. M., Greten, F. R., Li, Z. W., and Karin, M. (2002). Macrophage apoptosis by anthrax lethal factor through p38 MAP kinase inhibition. Science 297, 2048-2051. 
Pellizzari, R., Guidi-Rontani, C., Vitale, G., Mock, M., and Montecucco, C. (1999). Anthrax lethal factor cleaves MKK3 in macrophages and inhibits the LPS/IFNgamma-induced release of NO and TNFalpha. FEBS Lett. 462, 199-204.

Popov, S. G., Villasmil, R., Bernardi, J., Grene, E., Cardwell, J., Wu, A., Alibek, D., Bailey, C., and Alibek, K. (2002). Lethal toxin of Bacillus anthracis causes apoptosis of macrophages. Biochem. Biophys. Res. Commun. 293, 349-355.

Rainey, G. J., Wigelsworth, D. J., Ryan, P. L., Scobie, H. M., Collier, R. J., and Young, J. A. (2005). Receptorspecific requirements for anthrax toxin delivery into cells. Proc. Natl. Acad. Sci. U.S.A. 102, 13278-13283.

Rao, L. V., Ngyuen, M., and Pendurthi, U. R. (2004). Lethal toxin of Bacillus anthracis inhibits tissue factor expression in vascular cells. $J$. Thromb. Haemost. 2, 530-532.

Raymond, B., Leduc, D., Ravaux, L., Le Goffic, R., Candela, T., Raymondjean, M., Goossens, P. L., and Touqui, L. (2007). Edema toxin impairs anthracidal phospholipase A2 expression by alveolar macrophages. PLoS Pathog. 3, e187. doi:10.1371/journal.ppat.0030187

Reeves, C. V., Dufraine, J., Young, J. A., and Kitajewski, J. (2010). Anthrax toxin receptor 2 is expressed in murine and tumor vasculature and functions in endothelial proliferation and morphogenesis. Oncogene 29, 789-801.

Reig, N., Jiang, A., Couture, R., Sutterwala, F. S., Ogura, Y., Flavell, R. A., Mellman, I., and Van Der Goot, F. G. (2008). Maturation modulates caspase-1-independent responses of dendritic cells to Anthrax lethal toxin. Cell. Microbiol. 10, 1190-1207.

Ribot, W. J., Panchal, R. G., Brittingham, K. C., Ruthel, G., Kenny, T. A., Lane, D., Curry, B., Hoover, T. A., Friedlander, A. M., and Bavari, S. (2006). Anthrax lethal toxin impairs innate immune functions of alveolar macrophages and facilitates Bacillus anthracis survival. Infect. Immun. 74, 5029-5034.

Roberts, J. E., Watters, J. W., Ballard, J. D., and Dietrich, W. F. (1998). Ltx1, a mouse locus that influences the susceptibility of macrophages to cytolysis caused by intoxication with Bacillus anthracis lethal factor, maps to chromosome 11. Mol. Microbiol. 29, 581-591.

Ross, J. M. (1957). The pathogenesis of anthrax following the administration of spores by the respiratory route. J. Pathol. Bacteriol. 73, 485-494.

Rossi Paccani, S., Benagiano, M., Capitani, N., Zornetta, I., Ladant, D., Montecucco, C., D’Elios, M. M., and Baldari, C. T. (2009). The adenylate cyclase toxins of Bacillus anthracis and Bordetella pertussis promote Th2 cell development by shaping $\mathrm{T}$ cell antigen receptor signaling. PLoS Pathog. 5, e1000325. doi:10.1371/journal.ppat.1000325

Rossi Paccani, S., Tonello, F., Patrussi, L., Capitani, N., Simonato, M., Montecucco, C., and Baldari, C. T. (2007). Anthrax toxins inhibit immune cell chemotaxis by perturbing chemokine receptor signalling. Cell. Microbiol. 9, 924-929.

Scobie, H. M., Rainey, G. J., Bradley, K. A., and Young, J. A. (2003). Human capillary morphogenesis protein 2 functions as an anthrax toxin receptor. Proc. Natl. Acad. Sci. U.S.A. 100, 5170-5174.

Smith, H., and Keppie, J. (1954). Observations on experimental anthrax; demonstration of a specific lethal factor produced in vivo by Bacillus anthracis. Nature 173, 869-870.

Smith, H., and Stanley, J. L. (1962). Purification of the third factor of anthrax toxin. J. Gen. Microbiol. 29, 517-521.

Stanley, J. L., Sargeant, K., and Smith, H. (1960). Purification of factors I and II of the anthrax toxin produced in vivo. J. Gen. Microbiol. 22, 206-218.

Steele, A. D., Warfel, J. M., and D'Agnillo, F. (2005). Anthrax lethal toxin enhances cytokine-induced VCAM-1 expression on human endothelial cells. Biochem. Biophys. Res. Commun. 337, 1249-1256.

Sterne, M., and Robinson, E. M. (1939). The preparation of anthrax spre vaccines (for cattle and sheep) in South Africa. Onderstepoort J. Vet. Sci. Anim. Ind. 12, 9-18.

Sweeney, D. A., Cui, X., Solomon, S. B., Vitberg, D. A., Migone, T. S., Scher, D., Danner, R. L., Natanson, C., Subramanian, G. M., and Eichacker, P. Q. (2010). Anthrax lethal and edema toxins produce different patterns of cardiovascular and renal dysfunction and synergistically decrease survival in canines. J. Infect. Dis. 202, 1885-1896.

Szarowicz, S. E., During, R. L., Li, W., Quinn, C. P., Tang, W. J., and Southwick, F. S. (2009). Bacillus anthracis edema toxin impairs neutrophil actin-based motility. Infect. Immun. 77, 2455-2464.
Tang, S., Moayeri, M., Chen, Z., Harma H., Zhao, J., Hu, H., Purcell, R. H., Leppla, S. H., and Hewlett, I. K. (2009). Detection of anthrax toxin by an ultrasensitive immunoassay using europium nanoparticles. Clin. Vaccine Immunol. 16, 408-413.

Terra, J. K., Cote, C. K., France, B., Jenkins, A. L., Bozue, J. A., Welkos, S. L., Levine, S. M., and Bradley, K. A. (2010). Cutting edge: resistance to Bacillus anthracis infection mediated by a lethal toxin sensitive allele of Nalplb/Nlrp1b. J. Immunol. 184, 17-20.

Tessier, J., Green, C., Padgett, D., Zhao, W., Schwartz, L., Hughes, M., and Hewlett, E. (2007). Contributions of histamine, prostanoids, and neurokinins to edema elicited by edema toxin from Bacillus anthracis. Infect. Immun. 75, 1895-1903.

Tigertt, W. D. (1980). Anthrax. William Smith Greenfield, M.D., F.R.C.P., Professor Superintendent, the Brown Animal Sanatory Institution (1878-81). Concerning the priority due to him for the production of the first vaccine against anthrax. J. Hyg. (Lond.) 85, 415-420.

Tournier, J. N., Quesnel-Hellmann, A., Mathieu, J., Montecucco, C., Tang, W. J., Mock, M., Vidal, D. R., and Goossens, P. L. (2005). Anthrax edema toxin cooperates with lethal toxin to impair cytokine secretion during infection of dendritic cells. $J$. Immunol. 174, 4934-4941.

Tournier, J. N., Rossi Paccani, S., Quesnel-Hellmann, A., and Baldari, C. T. (2009). Anthrax toxins: a weapon to systematically dismantle the host immune defenses. Mol. Aspects Med. 30, 456-466.

Twenhafel, N. A. (2010). Pathology of inhalational anthrax animal models. Vet. Pathol. 47, 819-830.

van Sorge, N. M., Ebrahimi, C. M. Mcgillivray, S. M., Quach, D., Sabet, M., Guiney, D. G., and Doran, K. S. (2008). Anthrax toxins inhibit neutrophil signaling pathways in brain endothelium and contribute to the pathogenesis of meningitis. PLoS ONE 3, e2964. doi:10.1371/journal.pone.0002964

Vick, J. A., Lincoln, R. E., Klein, F. Mahlandt, B. G., Walker, J. S., and Fish, D. C. (1968). Neurological and physiological responses of the primate to anthrax toxin. J. Infect. Dis. 118, 85-96.

Vitale, G., Bernardi, L., Napolitani, G., Mock, M., and Montecucco, C. (2000). Susceptibility of mitogenactivated protein kinase family members to proteolysis by anthrax lethal factor. Biochem. J. 352(Pt 3), 739-745.

Voth, D. E., Hamm, E. E., Nguyen, L. G., Tucker, A. E., Salles, I. I., OrtizLeduc, W., and Ballard, J. D. (2005). Bacillus anthracis oedema toxin as a cause of tissue necrosis and cell typespecific cytotoxicity. Cell. Microbiol. 7, 1139-1149.

Wade, B. H., Wright, G. G., Hewlett, E. L., Leppla, S. H., and Mandell, G. L. (1985). Anthrax toxin components stimulate chemotaxis of human polymorphonuclear neutrophils. Proc. Soc. Exp. Biol. Med. 179, 159-162.

Warfel, J. M., Steele, A. D., and D'Agnillo, F. (2005). Anthrax lethal toxin induces endothelial barrier dysfunction. Am. J. Pathol. 166, 1871-1881.

Watson, L. E., Kuo, S. R., Katki, K., Dang, T., Park, S. K., Dostal, D. E., Tang, W. J., Leppla, S. H., and Frankel, A. E. (2007a). Anthrax toxins induce shock in rats by depressed cardiac ventricular function. PLoS ONE 2, e466. doi:10.1371/journal.pone. 0000466

Watson, L. E., Mock, J., Lal, H., Lu, G., Bourdeau, R. W., Tang, W. J., Leppla, S. H., Dostal, D. E., and Frankel, A. E. (2007b). Lethal and edema toxins of anthrax induce distinct hemodynamic dysfunction. Front. Biosci. 12, 4670-4675.

Webster, J. I., and Sternberg, E. M. (2004). Role of the hypothalamicpituitary-adrenal axis, glucocorticoids and glucocorticoid receptors in toxic sequelae of exposure to bacterial and viral products. J. Endocrinol. 181, 207-221.

Webster, J. I., and Sternberg, E. M. (2005). Anthrax lethal toxin represses glucocorticoid receptor (GR) transactivation by inhibiting GR-DNA binding in vivo. Mol. Cell. Endocrinol. 241, 21-31.

Webster, J. I., Tonelli, L. H., Moayeri, M., Simons, S. S. Jr., Leppla, S. H., and Sternberg, E. M. (2003). Anthrax lethal factor represses glucocorticoid and progesterone receptor activity. Proc. Natl. Acad. Sci. U.S.A. 100, 5706-5711.

Welkos, S. L., Keener, T. J., and Gibbs, P. H. (1986). Differences in susceptibility of inbred mice to Bacillus anthracis. Infect. Immun. 51, 795-800.

Welkos, S. L., Vietri, N. J., and Gibbs, P. H. (1993). Non-toxigenic derivatives of the Ames strain of Bacillus anthracis are fully virulent for mice: role of plasmid pX02 and chromosome in strain-dependent 
virulence. Microb. Pathog. 14, 381-388.

Wu, W., Mehta, H., Chakrabarty, K., Booth, J. L., Duggan, E. S., Patel, K. B., Ballard, J. D., Coggeshall, K. M., and Metcalf, J. P. (2009). Resistance of human alveolar macrophages to Bacillus anthracis lethal toxin. J. Immunol. 183, 5799-5806.

$\mathrm{Xu}$, L., Fang, H., and Frucht, D. M. (2008). Anthrax lethal toxin increases superoxide production in murine neutrophils via differential translocation. Annu. Rev. Biochem. 76, 243-265. J. Immunol. 180, 4139-4147.

Yeager, L. A., Chopra, A. K., and Peterson, J. W. (2009). Bacillus anthracis edema toxin suppresses human macrophage phagocytosis and cytoskeletal remodeling via the protein kinase A and exchange protein activated by cyclic AMP pathways. Infect. Immun. 77, 2530-2543. Young, J. A., and Collier, R. J. (2007). Anthrax toxin: receptor binding, internalization, pore formation, and
Conflict of Interest Statement: The authors declare that the research was conducted in the absence of any comcould be construed as a potential conflict of interest.

Received: 27 January 2012; accepted: 16 May 2012; published online: 01 June 2012. mercial or financial relationships that
Citation: Lowe DE and Glomski IJ (2012) Cellular and physiological effects of anthrax exotoxin and its relevance to disease. Front. Cell. Inf. Microbio. 2:76. doi: 10.3389/fcimb.2012.00076

Copyright (c) 2012 Lowe and Glomski. This is an open-access article distributed under the terms of the Creative Commons Attribution Non Commercial License, which permits non-commercial use, distribution, and reproduction in other forums, provided the original authors and source are credited. 